\title{
ACCEPTED FOR PUBLICATION
}

\section{Feminist Christian Realism:}

\section{Vulnerability, Obligation, and Power Politicsi}

\author{
Caron E. Gentry \\ University of St Andrews \\ School of International Relations \\ The Arts Building \\ The Scores \\ St Andrews KY16 9AX \\ UNITED KINGDOM \\ ceg1@st-andrews.ac.uk
}

Biography: Caron E. Gentry is a lecturer in the School of International Relations at the University of St Andrews. Caron's work has focused on gender and terrorism for over a decade. Having written on women's involvement in politically violent groups with articles in various journals her publications also include (with Laura Sjoberg) Mothers, Monsters, Whores: Women's Violence in Global Politics (Zed Books, 2007) and the edited volume, Women, Gender, and Terrorism (University of Georgia Press, 2011). She is also published in political theology with a focus on the Just War tradition and its relationship with marginalized persons in international affairs. Her most recent book is Offering Hospitality: Questioning Christian Approaches to War (University of Notre Dame Press, 2013).

\footnotetext{
Abstract: While Christianity and feminism may seem at odds with one another, both make normative claims about justice and addressing the needs of those on the margins of power. This paper explores what feminism contributes to Christian realism. The current revival of Niebuhrian Christian realism highlights how much it still has to offer as a
} 
theoretical underpinning for policy and governance. However, Christian realism remains wedded to masculinist abstractions and power structures, such as the balance of power, that are ultimately harmful to those on the margins. Thus, this paper uses feminism to argue for a greater acceptance of vulnerability and obligation in Christian realism.

Keywords: Feminism, Christian Realism, Abstraction, Obligation, Vulnerability

Christian realism enables a person formed by the Christian faith to make sense of international politics. From a theologically informed perspective, Christian realism provides a way to navigate power politics, injustices, and human vulnerability. However, the solutions that Christian realism holds as key and necessary, mainly the balance of power, are lacking when viewed from a feminist perspective. Thus, this paper will look at the relevance of Christian realism's longstanding work to all scholars of international relations as well as how feminism can push Christian realism into a better relationship with power.

This project may seem odd as being both a Christian and a feminist are seen as contradictory. There are obvious tensions between Christianity and feminism that strike at some of the fundamental elements of personhood (see Hampson $1988 \& 1990$ ). These include, but are not limited to, how the church has treated women, responded to the LGBTQ community, covered up the sexual abuse of children, and, historically, been 
complicit with, if not in flagrant support of, imperialism. Feminism's desire to empower the disempowered challenges this particularized patriarchal status quo. I would never deny the harm that the human institution of the church at large has done, but I believe there is more to any religion than its flawed human institutions. Christianity, like other faiths, is a spiritual and relational way of being that requires a follower to be concerned with injustice and to care for the marginalized (Elshtain 2000; Gentry 2015). In this, the central concerns of Christianity and feminism meet.

This paper explores what feminism contributes to Christian realism. The current revival of Niebuhrian Christian realism highlights how much it still has to offer as a theoretical underpinning for policy and governance (see Bacevich 2008a; Lovin 2007, 2008); however, deconstructing it could lead to a stronger theory that better accounts for how feminist revelations of gender lay bare transnational and sub-state problems (see Gentry 2013). While secular realism has found itself to be the recipient of necessary critiques, such as the feminist critique that it abstracts the nature of power and war (Enloe 1983, 1989; Tickner 1992; Sylvester 1999, 2002), Christian realism has not been forced to engage in similar conversations. Particularly, Christian realism is heavily reliant upon a pessimistic view of humanity in its belief that the human tendency for power-seeking leads to manipulation and exploitation (Niebuhr 1964, 164-5). Further, Christian realism has not dealt with the contemporary international problems that cannot be answered through its reliance upon a very masculinized and abstracted balance of power. 
Yet, Christian realism and feminism share some interesting commonalities: they both view individuals to be important actors in international affairs (Niebuhr 1932a; Elshtain 2000; Enloe 2010); they are both explicitly normative (Niebuhr 1932a, 1964); and neither attempts to be (necessarily) universalizing (Niebuhr 1932a; Sylvester 2002). Therefore, this paper posits that there is room in Christian realism to be transformed by feminism, with its recognition of gender construction, obligation, and power abstraction. Such transformations will conceivably enable Christian realism to leave behind its masculinized abstraction of international relations, its ignorance of obligation, and its structural violence towards marginalized populations. Through such a transformation, it may be possible to revisit the idea of justice that Christian realists value so highly and fall so short of achieving.

Thus, this paper will discuss the contribution Christian realism makes but also how it can be updated by feminism to better address contemporary issues. It begins by looking at Niebuhr's Christian realism before turning to more current Christian realist scholarship, with a particular focus upon Jean Bethke Elshtain. After this, Christian realism will be deconstructed through a feminist perspective. Doing so allows a scholar formed by Christianity to be informed by feminism. It illustrates what feminist Christian realism could be through a brief discussion of the humanitarian crisis on the Mexico-US border. Feminism helps soften the edges of Christian realism's blunt sword and seek a fairer justice and deeper peace while recognizing the reality of power in global affairs. 


\section{FROM NIEBUHR TO ELSHTAIN: CHRISTIAN REALISM AS A LIVING TRADITION}

Feminist Christian realism would trouble the relationship Christians have with power. Not only are there historical examples of the Church engaging in power-over, i.e., the Crusades, colonization, and the protection of pedophile priests, there are also some disturbing current examples, such as Pat Robertson calling for the assassination of Hugo Chavez, the refusal to allow women an equal role in church hierarchy, and the exclusionary stances against gay marriage. Strands within Christianity have struggled to address these power-overs: from the pacifism of the Quaker and dissenting churches (see Hauerwas 1983, Yoder 1994), the Marxism of liberation theology (Gutiérrez 1973), to the feminisms of Sarah Coakley (2002) and Marilyn McCord Adams (2006). While inroads into a feminist realism have been made, particularly by Jean Bethke Elshtain (2000, 2008), one has not emerged that completely considers how gender operates as a structuring force while taking the claims of Christianity seriously. The feminist Christian realism proposed here argues for a theological tradition that fully deliberates how the powerful are obliged to recognize the vulnerability of others, cultivating a level of care (see Gentry 2013), which is clarified in the use of the Mexico-US border crisis.

International relations has a long history with theology (Rengger 2013) and of IR scholars writing from a place informed by their faith, including modern scholars such as Reinhold Niebuhr, Jean Bethke Elshtain, and James Turner Johnson (1981). ${ }^{\text {ii }}$ Christian theologians have been working on the issues of peace and war since the early part of the 
first millennium, including Augustine's ancient political theology and Aquinas' medieval writings (for a discussion of this progression from a feminist perspective see Alkopher 2014, 262-3). Therefore, Christian theologians have grappled with issues of power, resistance to power, and power-over over a significant amount of time.

Their voices are important and theological voices from all perspectives are important because they contain some of the longest-standing perspectives. However well-developed these voices are, updating them to speak to current issues and events will always be a necessity. As it stands, Christian realism goes far in its historical and recent considerations of power, but, again, due to feminism's critical insight into power structures and the marginalized, feminism acts as a corrective. It helps us reconsider Christian realism's relationship with vulnerability, obligation, and power. To begin, this section will outline Neibuhr's approach to these before looking at the more recent work by Andrew Bacevich, Robin Lovin, and Nigel Biggar, with a particular focus on the feminism of Jean Bethke Elsthain.

\section{Niebuhrian Christian Realism}

In order to introduce such an extensive body of work, this paper will focus on three particular arguments that Niebuhr makes throughout the course of his career. First, if Niebuhr were to answer the question why war occurs, the fundamental cause is rooted in the human tendency to cling to fears and anxieties; in other words, war emerges from human vulnerability. Niebuhr is very aware that Christianity is a thick concept, just as 
other religions are thick concepts. Therefore, he believes the thinner concept of justice is the only idea that can reach across cultures and states as a way of organizing international relations (Niebuhr 1932; Thompson 1975, 286; Lovin 1995, 25-6, 70-1). Nonetheless, due to those inherent vulnerabilities and fears, Niebuhr believes humans seek power and primarily seek power at the expense of others. This leads to the second important argument: such power-seeking behavior is behind most, if not all, injustices in the world. Finally, in order to address injustice and the improper use of power, politicians and other leaders should establish and maintain a balance of power in all levels of society as the best way for establishing justice.

Contrary to Kenneth Waltz's assertion that Christian realists believe in the inherent "evilness" of humans $(1959,20-1)$, Niebuhr does not believe that humans are evil, but that they have a propensity towards securing their own position in a manner that pits them against others (Niebuhr 1964, 124, 164-5; see also Lovin 1995, 132). On their own or in intimate relationships humans can act morally, but larger groups bring out anxieties and an innate need for self-preservation (Niebuhr 1932b, 1956, 52). Human reality is one of freedom albeit limited by humans' finite knowledge and perfectibility. Humans can choose to do good but may choose otherwise. In the anxiety wrought by this freedom limited by human imperfectability, all pursuits become "infected" with pride, which upsets any concept of harmony (Niebuhr 1964, 178), resulting in the need to depend upon power (Niebuhr 1964, 124, 164-5, \& 185; Lovin 1995, 123). Therefore, Niebuhr declares that "the real evil in the human situation" is humanity's "inclination to grasp after a power and security" (Niebuhr 1964, 137; see also Williams 1986, 293). 
There are five different types of pride that Niebuhr identifies as problematic; of particular interest to international security is the pride of power (Niebuhr 1964, 188-203; see Williams 1986, 293). Thus, Christian realists are highly cognizant of how people use power to position themselves above others. Niebuhr $(1964,189)$ conceptualizes pride as having a dual nature: 1) humans imagine themselves to be secure; and 2) humans fear their insecurity and thus engage in the will-to-power. The first categorization of this form of pride is "particularly characteristic of individuals and groups whose position in society is, or seems to be, secure" (Niebuhr 1964, 189). The other categorization of the pride of power, the will-to-power, stems from insecurity. The problem with the will-to-power is that power is sought "at the expense of other life" (Niebuhr 1964, 182, 190). Seeking power over another is blatantly unjust (see Patterson 2003, 3-4). Thus, Christian realists are concerned with the creation of international norms, specifically ones concerned with the creation of social justice, while still dealing with the realities of political power (Patterson 2003, 8-10). According to Niebuhr the only way to deal with the reality of power is to find a way to balance it.

Any monopoly on power "generates injustices," which is why democracy (the form of government most favored by Niebuhr) is dependent upon checks and balances (Niebuhr 1962a, 156). The balance of power within the international system is itself a form of checks and balances and fosters its own form of justice (Niebuhr 1962a, 158; see also Ulrich 2006, 8; Lovin 2007, 57-8). This happens because new arrangements to solve disagreements are constantly being sought (Lovin 1995, 29). Further, balances remove 
anxiety from the equation on all sides. Niebuhr would have preferred a multipolar system (Ulrich 2006), but he was very much aware that such a system was not achievable during the Cold War and found workable solutions in containment and deterrence (Niebuhr 1962a, 156-7).

One can take from Niebuhr's Christian realism several important points. First, Niebuhr's understanding of human nature is deeply aware of how selfishness may lead to seeking power for security. Second, Niebuhr, at some level, is cognizant of the harmful effects of power-over dynamics. Finally, he is concerned with ethics, norms, and justice in human relations and the international system. However, these contributions do not make Niebuhr immune from criticism. As important as Niebuhr's works was, and is, as effective as the balance of power and use of deterrence were during the Cold War, Niebuhr could have better accounted for how such policies generated their own injustices.

\section{Recent Realisms}

Niebuhr's influence has been constant since his passing from public life in the late-1960s (see Childress 1974; McCann 1980; Williams 1986; Lovin 1995), but since the early 2000s multiple scholars have been part of an academic and public revival (Bacevich 2008a, 2008b; Lovin 2007, 2008; Elshtain 2003, 99-111; Biggar 2013). However, these works are very much a revival in the sense that they conservatively approach Niebuhr's work and do not necessarily take it in new and different directions. For instance, Andrew 
Bacevich's work is focused on the problematic militarization of the American Christian Right (2005) and his work on Niebuhr offers somewhat of a corrective to interpretations of Niebuhr (Bacevich 2008a). Political theologian Robin Lovin has published on Niebuhr for twenty-years (see Lovin 1995) and his 2008 book attempts to contemporize Niebuhr by extrapolating Niebuhr's approach to international power structures to an era of globalization. Finally, Nigel Biggar's (2013) recent work on Just War claims to be coming from a Christian realist perspective. In a brief section, Biggar (2013) looks at Niebuhr's ideas of love and justice (73-5), before making his own argument for a Christian and political need for retributive justice as enacting "love in war" (76-91) (which misrepresents Niebuhr's distinction between the operations of love and justice in politics). While each scholar offers something important in their own right, their work stays focused on what is problematic in Christian realism: abstractions of power, whether it looks at political mechanizations, globalized wealth and technology, or militarized justice. As a feminist political theologian, the impressive Jean Bethke Elshtain came closest to articulating a feminist Christian realism.

Elshtain mainly focused on political theory, particularly the Just War tradition (1992), which she explored from a feminist perspective in Women and War (1987). As a theologian, her later work expressed her desire to be a voice against injustice in the world, which Elshtain succinctly explains in her small theology, Who Are We? Critical Reflections and Hopeful Possibilities (2000). In essence, God created humans to be in relationship with the Creator ${ }^{\mathrm{iii}}$ and each other. There is an immense call to sociality- to living within communion (or community). This is referred to as living within the imago 
dei (Elshtain 2000, 13-18). ${ }^{\text {iv }}$ By living within the imago dei, humans are granted a (relational) freedom - they are free to do what they like as long as it within the boundaries of imago dei. Simply put, the golden rule that is present in a variety of cultures and traditions captures this: do unto others as you would have done unto you. But more than that, in this social call Christians are meant to live as witnesses and to be attendant to the horrors and injustices of the world (Elshtain 2000, 127-128; see also Adams 2006, 71-72). Christians are not meant to sit idly by while injustices occur; Christians are meant to actively speak and move against them. ${ }^{\mathrm{v}}$

While Elshtain focuses on domestic issues in Who Are We? this desire to speak out against injustices internationally can be found in two later books, Sovereignty: God, State, and Self (2008) and The Just War Against Terror: The Burden of American Power (2003). In the former, due to Elshtain's belief in communion-ity and justice, she envisions sovereignty as a moral, ethical authority stemming from a loving relationship between God and creation, and the state and individual. Her call to live socially and intentionally is a call of obligation to recognize how humans are vulnerable to abuses of power (injustice). Yet, Elshtain seems very comfortable with the use of power at times, in a way that seemingly violates feminist positions. It has long been argued that sovereignty and autonomy are masculine traits (see Tickner 1992, 42). And in Sovereignty (2008) and The Just War Against Terror (2003), Elshtain appears too comfortable with hegemonic power and the hegemonic power of the US in particular. The sub-title, ...The Burden of American Power, is reflective of Christian realism's dubiousness towards power. It contains a brief discussion of the relevance to Niebuhr in a post-9/11 world (see Elshtain 
2003, chapter 7), yet the main text evaluates the justness of the US invasion of

Afghanistan in 2001. While her concern over this issue furthers her ethos, it falls short of the goal. This work is criticized for her articulation of US exceptionalism (O’Driscoll 2007, 488-89), particularly when she identifies all good with Western values and all bad with Eastern/Muslim values (Elshtain 2003, 3, 6, 23-4, 26-45), as well as for over-valuing the use of American might (Rengger 2004, 114-5). Thus, a feminist Christian realism, incorporating the strengths of Christian realism's desire to do justice and feminism's understanding of power hierarchies, would correct some of the dynamics seen in recent realisms.

\section{FEMINIST REVELATIONS}

While Christian realism is a rich and nuanced theological account of international relations, it is not satisfying. As stated at the beginning, Christians are informed by a desire to see justice done, establish a deep peace, and reach marginalized peoples. Feminism has also informed me on these points. Thus, when I read Niebuhr (and other Christian realists) through the feminist lens that Tickner, Enloe, and Sylvester (amongst many others) have taught me, I see deep flaws within these arguments. Feminists in international relations have revealed how masculine ideals are transposed upon the construction of 'the international system' in a way that ignores, negates, or simply fails to acknowledge the role women (are forced to) play. As such, feminism is critical of the perpetual neo-realist focus upon the third-level, which abstracts the true reality of the causes of war and the role individuals play in war (Tickner 1992, 2004; Blanchard 2003). 
For instance, Cynthia Enloe's Nimo's War, Emma's War (2010) uses the stories of eight women to highlight how women's lives are impacted by war, which de-abstracts war in the profoundest way possible. Many feminists also bring the concept of obligation and relational autonomy into the equation, which highlights structural violence (Hirschmann 1992; Sylvester 2002). Such arguments make it clear to me how ignorant Niebuhr was about the implications of focusing upon structural power (im)balances.

In Feminist International Relations: An Unfinished Journey (2002), Sylvester briefly presents the perspectives and key questions of various feminist approaches to IR. Because her presentation is familiar to this audience, this presentation of her work will be brief. Similarly to other feminist approaches postmodern feminism forces scholars to grapple with "how we think, or do not think, or avoid thinking about gender" (Sylvester 2002, 177), which is crucial to deconstructing Christian realism. Like other forms of postmodern thinking, postmodern feminists "embrace a posture of uncertainty, about 'the self, gender, knowledge, social relations, and culture (understood by) linear, teleological, hierarchical, holistic, or binary ways of thinking and being"' (Flax 1987, 622 as quoted in Sylvester 2002, 177). The most obvious, troubling binary to feminism is the divide between masculinity and femininity and how this extends into IR's approach to the state system, which is itself a binary between the legitimacy and primacy of the state versus almost all other actors (Tickner 1992, 7-8, 42).

Nevertheless, (postmodern) feminists are skeptical of how 'reality' is constructed primarily by those in power and how this avoids allowing for a diversity of experiences 
and perspectives: universalizing positions are written by those in power and therefore "ignore the impact of class, race, and culture on identities and lived experiences" (Sylvester 2002, 177). Thus feminists are dubious of those who claim to have a 'realist(ic)' grasp on the international system and how the power dynamics within it operate. Such positions create a flattened/abstracted perspective about the world and 1) ignore the problems inherent in gender, racism, elitism, and ethnocentrism as well as 2) fail to be enriched and enlivened by incorporating perspectives from below the state level. Niebuhr, even with his supposed understanding of human nature and his commitment to social justice, wrote in a gender-blind, not to be confused with genderneutral, time and therefore his work deserves updating on this front.

Inflating IR from the flattened structural perspective relies upon making "sense of international politics [by] read[ing] power backwards and forwards" (Enloe 2000, 196). Reading power backwards and forwards involves grasping how the international impacts lives in a way that abstract conceptions of power cannot. Abstraction prevents this from happening because it 'paints' security in broad terms; in other words, abstraction occurs when international relations scholars and practitioners become wedded to generalizations used to explain various events as discreet, neutral, and solitary units, such as 'the balance of power' (see Sylvester 1999, 34-5). The individual is virtually absent and thereby ineffective, and somehow also unaffected, by the activities states engage in (Sylvester 2002, 160-1). The process of abstraction also "transposes" idealized masculine traits, such as autonomous, rational, logical, powerful (and therefore just), upon the state (Sylvester 2002, 160-1; see also Peterson and Runyan 2010, 38). The only way such 
thinking translates to security is to think in terms of 'hard power,' or to think about the rationality, capability, and sovereignty of the state. Focus upon state sovereignty and power, of which protection of the population is only one aspect, detracts from and abstracts the reality of individuals' security and displays a disregard for the safety of other states' peoples.

Masculinized sovereignty and its relationship to the Westphalian abstraction denies any sense of vulnerability and obligation. All stripes of realism, neo- here but Christian as well, promotes the notion of invulnerability through the balance of power and deterrent policies - if we build it (arms), they won't come (attack). Feminism rejects this claim because women's lives and experiences have been ones of obligation and vulnerability, as either imposed ideas of what it means to be a woman in international relations, i.e. the conflation 'womenandchildren' (Enloe 1993) or of the actuality of abuse, exploitation, and lack of access and/or care towards women and other marginalized people groups (Sylvester 2002). And while many masculinized writings in international relations would deny obligation, life and, subsequently, IR are negotiations of obligation and interdependence. This vulnerability is something that Niebuhr tacitly acknowledges in international politics. While it underpins his theology on anxiety and freedom, it is something that he wishes to deny or mitigate in international politics. Herein lies the problem. Niebuhr had a complicated relationship with how to respond to the then thirdworld countries. Whereas Lovin (2008) wanted to update Niebuhrian Christian realisms by looking at globalization, I wish to update and hopefully better Christian realism by 
looking at how those in the developing world are treated by addressing the crisis at the Mexico-US border.

\section{Responding to the Marginalized}

One way of approaching a feminist Christian realism is to look at how obligation and vulnerability may build an approach to the humanitarian crisis on the Mexico-US border. Over the past three years, the number of unaccompanied children from El Salvador, Guatemala, Honduras, and primarily Mexico arriving at the Texas border has spiraled, leading to a crisis point in the summer of 2014 (UNHCR 2014; Dart 2014). Known as 'the surge' the 57,000 children that have arrived between late autumn 2013 and midsummer 2014 can no longer be adequately cared for (UNHCR 2014, 15). Newspapers have compared the unsanitary and crowded conditions at the detention centers to refugee camps (Dart 2014), but the comparison is moot as these are in fact refugee camps. The children are fleeing familial, gang, sexual, and cartel violences that require international protection according to the UNHCR (2014).

The 2014 UNHCR, Children on the Run, interviewed 404 children in the centers from all four Central American states. Fifty-eight percent of the 404 children "suffered or faced harms that indicated a potential or actual need for international protection" (UNHCR 2014, 6 \& 17). Twenty-one percent faced abuse at home (UNHCR 2014, 6). Mexican children compose the largest population, reaching 18,754 in 2013 up from 13,000 in 2011, and 38 percent faced "recruitment and exploitation by the criminal industry of 
human smuggling"- in other words, they were helping 'coyotes' (human smugglers) move migrants over the Mexico-US border (UNHCR 2014, 5-6). While much of the reporting has made the existence of the unaccompanied children's arrival at the US border the problem, the UNHCR report recommends the international community recognize two points. First, that the children are children with particular needs and greater vulnerability (UNHCR 2014, 11). Second, the children are a symptom of a much larger problem: significant internal and regional conflict in these states (UNHCR 2014, $11)$.

While the political parties within the US have made this into a partisan issue, where national security and social justice are in direct competition (Nakamura and Tumulty 2014), this contested binary is not helpful. It is more important to recognize the US' own role in perpetuating these conflicts. In a Washington Post interview, Honduran President Orlando Hernandez "indicated" that responsibility lay with the US' "heavy-handedness" in the war on drug alongside the US demand for drugs, which "generates violence, reduces opportunities, [and] generates migration" (Tharoor 2014). Drug manufacturing moved into Central America from parts of Mexico and Colombia after the US and those states use militarized violence to crack down on the cartels (Hagopian 2014). The drug trade was not eliminated, it simply moved to another state in order to meet the high-level of demand coming from the US; this is known as the "balloon effect." In these cases, it has moved into states that do not have strong enough government institutions to fight such intense criminal activity (Lopez 2014). 
In a previous publication, I argue that within a feminist theology of conflict, powerful states must recognize their role in the problems of less powerful states (Gentry 2013, 378). While the children have created a 'problem' for the US, 'dealing' with the children will not fix the problem. Instead, the US is obligated to recognize its role in the root of the problem: the endemic violence due to drugs in Central America. It is not that 'traditional' Christian realists would be callous towards these children or about the reasons that forced them to seek refuge in the US. Indeed, they would be highly sympathetic. Still, the solutions and answers offered by Christian realism do not address the individual within international relations. For instance, when Lovin focuses on globalization, he missed the opportunity to look at how globalization affects individuals — what a globalized economy means for a Filipino nanny in Japan (see for instance Ehrenreich and Hochschild 2003), to be a young girl in rapidly developing China (see for instance Kristof and WuDunn 2009), or to be children in states ravaged by the globalized narcotics trade_- by staying focused effectively on the third level of analysis.

Niebuhr's own abstraction is perhaps the most surprising. He began his career as an inner-city minister in Depression-era Detroit driven by socialist ideals, purposefully supporting the working-class African-American community. Moral Man and Immoral Society's (1932a) main argument is that love can exist within individual relationships and small communities, but it is lost in political arrangements. Instead, political life should be ordered by justice, which, to reiterate, requires balancing. Yet, this is where the problem emerges. In his international relations scholarship, Niebuhr's concentration on structural dynamics of the balance of power deflected from how the negative peace of deterrence 
affected the then third-world. For instance, when contemplating the threat of communism in 'peripheral' locations, such as the developing world, versus the heart of the West, Europe, he was far more comfortable with letting the periphery fall to communism (Niebuhr 1962a, 157).

If we return to the humanitarian crisis on the Texas border, would the response to the conflicts that led to this crisis be any different? As these conflicts exist in deeply impoverished states with large drug cartels and high-level gang violence, would a traditional Christian realist response be one that abstracted the refugee children to a national security threat? This seems anti-thetical to the emphasis on justice. Instead, a feminist Christian realism would insist upon recognizing the extreme vulnerability of not just the 57,000-plus children amassed in unacceptably over-crowded centers, but also the obligation for working with El Salvador, Honduras, Guatemala, and Mexico in addressing the root of the problem.

\section{TOWARDS A FEMINIST CHRISTIAN REALISM}

In constructing 'security' and (negative) 'peace' in international relations, Niebuhr fails to recognize the reality of vulnerability and hence obligation. Niebuhr's thinking is committed to binaries (even if he attempts to trouble them) - his thinking is masculinist and prone to concerns about power versus weakness - valuing a justice that comes from power. As such, he cannot recognize that the structures he writes about and works within

create obligations beyond what he acknowledges. He knows that social organizations are 
flawed, yet can he recognize that such organizations require different things of different people? (As a former socialist cognizant of social injustice, surely he can.) At the heart of this puzzle is human vulnerability.

Vulnerability is a tricky concept to feminists because of its inherent connection to obligation. To begin, "human life is conditioned by vulnerability" wrought by our embodiment, sociality, and political structures (Mackenzie, Rogers, and Dodds 2014, 1). Judith Butler (2006) approaches vulnerability through her discussions on the precariousness of whose lives are or are not worthy or grievable. Vulnerability, in Butler's work, is also identified by the weaknesses of human bodies and/or psyches and the possibility of being harmed by an other (Butler 2009, 2). Further, vulnerability emerges from a self's encounter with an other and the mutual recognition of each self's ability to harm or destroy the other (see Butler 2009; Levinas 2006). In this mutuality of destruction, obligation of one to an other exists (Levinas 2006, 64). Yet, as Daphne Hampson, a post-Christian feminist theologian, points out, obligation, which can be linked to submission within the Christian religion, is not equal between the sexes, more is required of women than of men. ${ }^{\mathrm{vi}}$ While Sarah Coakley (2002) as a feminist theologian redeems this concept, she does so by accepting that a certain level of vulnerability is required equally of both men and women. As Christine Sylvester has pointed out, most realists, Christian or neo-, deny obligation and vulnerability (2002). It follows that mutual vulnerability is missing from Niebuhr's account of international affairs - he finds vulnerability in the developing world more acceptable than allowing for any in the West. 
The concept of human security engages a notion of obligation as dependent upon vulnerability. Human security is more focused upon the individual rather than on the global structure: "the security of people — their physical safety, their economic and social well-being, respect for their dignity and worth as human beings, and the protection of their human rights and fundamental freedoms" (ICISS 2001, 15). Some see human security as a natural fit with feminist scholarship in IR (Hoogensen \& Rottem 2004). Obligation connects with the notions of respect, dignity, worth, and in engaging the necessity of protection towards others and not just a realist concept of self-interest. Judith Butler has termed this sensibility "precarity—that all human life is precarious and vulnerable deserving of protection" $(2009,14)$. Precarity and obligation are only recognized in the face of the self's acknowledgment of its own vulnerability and such a vulnerability must be accorded to the other (if the other is to be fully accorded the status of human) (see Levinas 2006, 28, 64). Unless one views populations at risk as less than human and therefore less deserving of protection (which unfortunately happens all too frequently), then there is a responsibility to actively promote the total welfare of the other person. This is why there is no one solution to the drug-fueled conflicts in Central America and certainly not a militarized one borne from national security fears. Instead, there is an obligation of the powerful US (and international community) to working with the Central American states.

Yet, even in this recognition of obligation and 'precarity' is a power dynamic that is not easily overcome - of how the powerful relate to the powerless. Butler, as well as Levinas (2006), might keep this power dynamic in check because there is not just a mutual 
recognition of vulnerability, but also an obsession with doing what is good for the other (Levinas 2006, 64). Yet, the Global North does not often recognize its own troubled relationship with power, whether that power is about race relations, gender, or class. If we were to truly become obsessed with doing what is good for the other, it would not be to cast blame onto the weaker parties. Instead, such obsession would also take responsibility for problems closer to home while working alongside the disempowered elsewhere. As just one example Niebuhr has a significantly difficult time distinguishing between self-interest, responsibility, and what is best for the other. This difficulty inevitably leads to the articulation of structural (and manifest) violence against the populations of the developing world during the Cold War. It is seen most recently in treating the children as the problem instead of recognizing them as a very vulnerable 'symptom.' An obsession for doing what is right by those children would begin with addressing the demand for drugs within the US and the adherence to militarized policies by the US to address the drug supply in the Central American states, which puts lives and societies at risk. There is both responsibility-taking in this and an obsession with what is good for the other.

\section{Valued Added}

While a form of feminist Christian realism exists within theological circles (see Miles 2001), its focus is limited and thus limited in what it offers in the context and study of global politics. Feminism does contribute to political Christian realism as well and has the ability to transform it. The most serious challenge to the 'feminist Christian realism' 
project is a rejection of metanarratives for their totalizing and universalizing tendencies. Anything informed by a theology is going to have something of a universalizing tendency. Even if Niebuhr wished to avoid that route, Christian notions are laced throughout his work and the work of subsequent Christian realists.

But this is not to say that feminisms do not contain their own metanarratives. Several authors have pointed out that a feminism that does not take into account the periphery and/or the dogmatism of human security are metanarratives (Sylvester 2002, 302-303; Hudson 2005). Arguably, anything with a normative bent has a somewhat universalizing claim: whether it is gender equality or justice. Thus, what is important is to be constantly aware and critical of how much power is held and where it might be used. The Christian realist in me would say the inclination for power is unavoidable; the feminist Christian realist in me says that I should be aware always of the big stick, not as a method for coercion, but as a way of keeping myself in check because a prima facie duty of a self is to accord others their own humanity and vulnerability.

Therefore, a deconstruction of Christian realism from a feminist perspective serves both Christianity and feminism while eroding the Christian/feminist binary: feminists and Christian realists alike must realize that obligation is not one-sided and it is not necessarily benign. Obligation and the accordance of vulnerability tends to come from the 'haves' towards the 'have-nots' and there is no small power implication in this. If those in power feel compelled (obligated) to empower those identified as "lesser," there is a hopeful sense of justice, but there can also be coercion. The conglomerate inheritor of 
the First World identity, whether its labeled the Global North or the West, is often constructed as the entity that does not need help. Within the humanitarian crisis, it might be easy to point the finger at the Central American states, constructing them as in crisis or failing without recognizing the West's or US' role in it. Pointing the finger puts the entire obligation for stability creation on the Central American states and none on the state(s) potentially more responsible.

Global governance policy prescriptions that lead to the security of all humans should be preferable to all, but it should not happen as activities that only flow from the developed world as "those who have it right" to the developing world as "those who can't get it together." Obligation without this level of mutual vulnerability is just arrogance. Obligation with vulnerability opens up the various states and the actors within them (or wherever they may be) to truer ideas of justice and ones that help avoid latent, unseen structural violences.

Feminism helps strengthen Christian realism by pointing out what it is missing. In some ways, this turns Christian realism on its head because some of these addressed flaws allow Christian realism to do something it has never been comfortable with or even believed in: a recognition of mutual vulnerability between those in power and those outside of it. If vulnerability accords obligation, mutual vulnerability accords an obligation that is not patronizing or further disenfranchising. 
Christian realism as deconstructed by feminism would be committed to justice that takes better account of how international power affects lives-how US militarized responses to the drug trade and cartels is damaging to individuals and societies and how US drug demand fuels these fires. Knowing that Niebuhr was committed to social justice means this should not be a stretch, but his work on deterrence and the Cold War clearly illustrates that he gave into his own anxieties about the Soviet Union. Such anxiety enabled his own propensity to a power-over situation in which he sacrificed the justice and rights of people in the developing world. Feminism and its commitment to recognizing the marginalized and disenfranchised can redeem Christian realism by requiring it to obsessively want what is good for the other, not just the self. Inverting selfinterest allows for global policies that help those on the margins, like these children fleeing endemic violence that stems not just from their homes and societies but Western misuses of military and economic power.

\section{CONCLUSION}

Feminist Christian realism would advocate for practices that avoid further disenfranchisement and marginalization. Instead, feminist Christian realism would ask for self-critical policies that look at how power is manifested across boundaries, even when this is unintended. True self-interest, in my estimation, is an interest that wishes to see all communities, whether local or global, flourish. Christian and secular realist selfinterest is less interested in such flourishing, which in the end, contributes to insecurity. 
Yet, feminists, along with others who are proponents of human security, would be right to walk dubiously and carefully towards the 'salvation' of human security. Each time that an answer is claimed and proclaimed no small amount of power and therefore force is placed behind the proclamation. This may be a power used to create justice, but taking a leaf from the Christian realists, human tendency is all too likely to use that power to serve a self-interest.

Therefore, it is helpful to build a self-interest from vulnerability and obligation. It is from vulnerability that humans and states try to build security. But when security is built at the expense of others, it denies them their vulnerability and denies our own. It seeks to ascertain a state of being that simply cannot be (absolute security). But a self-interest that recognizes the self's vulnerability and therefore the other's vulnerability becomes based upon mutual obligation for each other's security. And when vulnerability and mutual obligation are recognized, so is the understanding that 'our' security is only as secure as 'other's' insecurity.

\footnotetext{
${ }^{\mathrm{i}}$ I would be remiss if I did not thank two of my mentors: first, Nick Rengger for saying that this was an article I needed to write; second, Fred Aquino for being an excellent professor and friend. Finally, I would also like to thank Tony Lang for an early reading and the three anonymous reviewers for their constructive criticisms that strengthened this article.
} 
ii I chose to reference Johnson's 1981 book, Just War and the Restraint of War, because of his discussion on Christian discipleship via contemplation and intentionality and the Just War tradition (1981, xxx-xxxiii).

iii I believe God transcends gender and will avoid using pronouns to refer to God-theCreator throughout this article.

${ }^{\text {iv }}$ Imago dei translates as the image of God and it refers to the community of believers as in communion with God and with each other-reflecting God's image (see Elshtain 2000, 13-8).

${ }^{v}$ I hasten to add that Christians are not alone in their calling to address injustice. The other major faith traditions, including Islam, Buddhism, and Hinduism, also believe in an active engagement, driven by their own metaphysical commitments, to speak out against injustice (see Gentry 2015).

${ }^{\text {vi }}$ Hampson, as well as other theologians, have explored a feminist Christian realism from a distinctly moral/ethical theological perspective and less so for any implications towards international relations (Hampson 1990; Miles 2001).

\section{Bibliography}

Adams, Marilyn McCord. 2006. Christ and Horrors: The Coherence of Christology. Cambridge: Cambridge University Press.

Alkopher, Tal Dingott. 2014. "Injury in Just War Theory: From the Traditional to the Feminist Perception." Cooperation and Conflict 49 (2): 260-75. doi: $10.1177 / 001083671452505$

Bacevich, Andrew. 2008a. "Prophets and Poseurs: Niebuhr and Our Times." World Affairs 170 (3): 24-37. Available at: http://www.worldaffairsjournal.org/article/prophetsand-poseurs-niebuhr-and-our-times (date accessed 8 August 2014). 
Bacevich, Andrew. 2008b. "Illusions of Managing History: The Enduring Relevance of Reinhold Niebuhr." Bill Moyers Journal, 15 August, available at:

http://www.pbs.org/moyers/journal/08152008/profile3.html (date accessed 1 December 2008).

Bacevich, Andrew. 2005. The New American Militarism. Oxford: Oxford University Press.

Biggar, Nigel. 2013. In Defence of War. Oxford: Oxford University Press.

Blanchard, Eric M. 2003. "Gender, International Relations, and the Development of Feminist Security Theory." Signs: Journal of Women in Culture and Society 28 (4): 1289-1312. doi: 0.1086/368328

Butler, Judith. 2009. Frames of War: When is Life Grievable? London: Verso Books.

Butler, Judith. 2006. Precarious Life: The Powers of Mourning and Violence. London: Verso Books.

Childress, James F. 1974. "Reinhold Niebuhr's Critique of Pacifism." The Review of Politics 36 (4): 467-491. doi: 10.1017/S0034670500024232

Coakley, Sarah. 2002. Powers and Submissions: Spirituality, Philosophy and Gender. Malden: Blackwell.

Dart, Tom. 2014. "Rio Grande Border to U.S. Sees 57,000 Young Migrants in Nine Months." The Guardian, http://www.theguardian.com/world/2014/jul/12/rio-grandeborder-us-united-states-children-migrants (accessed 8 August 2014).

Ehrenreich, Barbara and Arlie Russell Hochschild, eds. 2003. Global Woman: Nannies, Maids, and Sex Workers in the New Economy. London: Macmillan.

Elshtain, Jean Bethke. 2008. Sovereignty: God, State, and Self. New York: Basic Books.

Elshtain, Jean Bethke. 2003. Just War Against Terror: The Burden of American Power in a Violent World. New York: Basic Books.

Elshtain, Jean Bethke. 2000. Who Are We? Critical Reflections and Hopeful Possibilities. Grand Rapids: Eerdmans.

Elshtain, Jean Bethke, ed. 1992. Just War Theory. New York: New York University Press.

Elshtain, Jean Bethke. 1987. Women and War. New York: New York University Press. Enloe, Cynthia. 2010. Nimo's War, Emma's War. Berkeley: University of California Press. 
Enloe, Cynthia. 2000. Maneuvers: The International Politics of Militarizing Women's Lives. Berkeley: University of California Press.

Enloe, Cynthia. 1989. Bananas, Beaches, and Bases: Making Feminist Sense of International Relations. Berkeley: University of California Press.

Enloe, Cynthia. 1983. Does Khaki Become You: The Militarization of Women's Lives. London: Pluto Press.

Flax, Jane. 1987. "Postmodernism and Gender Relations in Feminist Theory." Signs: Journal of Women in Society and Culture 12 (4): 621-643.

http://www.jstor.org/stable/3174206

Gentry, Caron E. 2015. "Religious Approaches to Peace through Non-Violence." In Dimensions of Peace: Disciplinary and Regional Approaches, edited by Oliver Richmond, Sandra Pogodda, and Jasmin Ramovic, TBD. Houndmills: Palgrave Macmillan.

Gentry, Caron E. 2013. Offering Hospitality: Questioning Christian Approaches to War. South Bend: University of Notre Dame Press.

Gutiérrez, Gustavo. 1973. A Theology of Liberation. Maryknoll, NY: Orbis Books.

Hagopian, Joachim. 2014. “America's 'War on Drugs' Has Triggered a 'Humanitarian Crisis' in Central American Children Converging at the US Border." Global Research, 8 July, http://www.globalresearch.ca/americas-war-on-drugs-has-triggered-a-humanitariancrisis-in-central-american-children-converging-at-the-us-border/5390491 (accessed 13 August 2014).

Hampson, Daphne. 1990. Theology and Feminism. Oxford: Basil Blackwell.

Hampson, Daphne. 1988. "Luther on the Self: A Feminist Critique." Word and World 8 (4): $334-343$.

Hauerwas, Stanley. 1983. The Peaceable Kingdom. Notre Dame: University of Notre Dame Press.

Hirschmann, Nancy J. 1992. Rethinking Obligation: A Feminist Method for Political Theory. Ithaca: Cornell University Press.

Hoogenson, Gunhild. and SveinVigeland Rottem. 2004. "Gender Identity and the Subject of Security." Security Dialogue 35 (2): 155-171. doi: 0.1177/0967010604044974

Hudson, Heidi. 2005. "Gender and the Politics of Human Security." Security Dialogue 36 (2): 155-174. doi: 10.1177/0967010605054642 
International Commission on Intervention and State Sovereignty. 2001. The Responsibility to Protect. Ottawa: International Development Research Centre.

Kristof, Nicholas D. and Sheryl WuDunn. 2010. Half the Sky: Turning Oppression into Opportunity for Women Worldwide. New York: Random House.

Johnson, James Turner. 1981. Just War Tradition and the Restraint of War. Princeton: Princeton University Press.

Levinas, Emanuel. 2006. Humanism of the Other. Chicago: University of Illinois Press.

Lopez, German. 2014. "How the War on Drugs Drives the Child Migrant Crisis." The Vox, 23 July, http:/www.vox.com/2014/7/23/5925157/drug-war-child-refugeeimmigration-crisis (accessed 13 August 2014).

Lovin, Robin W. 2008. Christian Realism and the New Realities. New York: Cambridge University Press.

Lovin, Robin W. 2007. "Christian Realism and the Successful Modern State." Studies in Christian Ethics 20 (1):55-67. doi: 10.1177/0953946806075488

Lovin, Robin W. 1995. Reinhold Niebuhr and Christian Realism. New York: Cambridge University Press.

Mackenzie, Catriona, Wendy Rogers, and Susan Dodds. 2014. "Introduction: What is Vulnerablity and Why Does It Matter for Moral Theory?" In Vulnerability: New Essays in Ethics and Feminist Philosophy, edited by Catriona Mackenzie, Wendy Rogers, and Susan Dodds, 1-29. Oxford: Oxford University Press.

McCann, Dennis P. 1980. "Hermeneutics and Ethics: The Example of Reinhold Niebuhr." The Journal of Religious Ethics: 27-53. http://www.jstor.org/stable/40017735

Miles, Rebekah L. 2001. The Bonds of Freedom: Feminist Theology and Christian Realism. Oxford: Oxford University Press.

Nakamura, David and Karen Tumulty. 2014. 'Gov. Perry to Send National Guard Troops to Mexican Border Amid Migrant Crisis,' The Washington Post, July 14, http://www.washingtonpost.com/politics/perry-to-send-national-guard-troops-tomexican-border-amid-migrant-crisis/2014/07/21/499feb5a-110c-11e4-98eedaea85133bc9_story.html (accessed 8 August 2014).

Niebuhr, Reinhold. 1964. The Nature and Destiny of Man, Volume 1. New York: Charles Scribner's Sons.

Niebuhr, Reinhold. 1962a. "American Hegemony and the Prospects for Peace." Annals of the American Academy of Political and Social Sciences 342, July: 154-160. 
Niebuhr, Reinhold. 1962b. "History as Seen from the Radical Right." The New Leader 45, 16 April, 24.

Niebuhr, Reinhold. 1961. "Living with Fear," The New Leader 44, 13 November, 23.

Niebuhr, Reinhold. 1956. An Interpretation of Christian Ethics. New York: Meridian Books.

Niebuhr, Reinhold. 1932a. Moral Man and Immoral Society. New York: Charles Scribner's Sons.

Niebuhr, Reinhold. 1932b. 'Must We Do Nothing?' Christian Century, 30 March, 415417.

O’Driscoll, Cian. 2007. “Jean Bethke Elshtain's Just War against Terror: A Tale of Two Cities.” International Relations 21 (4): 485-92.

Patterson, Eric. 2003. "Niebuhr and His Contemporaries: Introduction to Christian Realism." In Reinhold Niebuhr and His Critics: Reassessing the Contributions of Niebuhr and His Contemporaries, edited by Eric Patterson, 1-24. Lanham: University Press of America.

Peterson, V. Spike and Anne Sisson Runyan. 2010. Global Gender Issues in the New Millennium. Boulder, CO: Westview Press.

Rengger, Nicholas J. 2013. “On Theology and International Relations: World Politics Beyond the Empty Sky.” International Relations 27 (2): 141-157.

Rengger, Nicholas J. 2004. "Review: Just a War Against Terror? Jean Bethke Elshtain's Burden and American Power." International Affairs 80 (1): 107-16.

Sylvester, Christine. 2002. Feminist International Relations: An Unfinished Journey. Cambridge: Cambridge University Press.

Sylvester, Christine. 1999. Feminist Theory and International Relations in a Postmodern Era. Cambridge: Cambridge University Press.

Tharoor, Ishaan. 2014. "One Chart that Explains the U.S. Border Crisis." The Washington Post, 29 July, http:/www.washingtonpost.com/blogs/worldviews/wp/2014/07/29/onechart-that-explains-the-u-s-border-crisis/ (access 8 August 2014).

Tickner, J. Ann. 2004. "Feminist Responses to International Security Studies." Peace Review, March 16 (1): 43-48. doi: 10.1080/1040265042000210148

Tickner, J. Ann. 1992. Gender in International Relations: Feminist Perspectives on Achieving Global Security. New York: Columbia University Press. 
Thompson, Dennis L. 1975. “The Basic Doctrines and Concepts of Reinhold Niebuhr's Political Thought." Journal of Church and State, 17: 275-299.

Ulrich, Andy. 2006. "Balance Democracy with Power: Responsibility, Order, and Justice in Reinhold Niebuhr's World View, 1940-1949." James A. Rawley Graduate Conference in the Humanities, Available at http://digitalcommons.unl.edu/historyrawleyconference/3 (accessed 4 November 2008), 1-21.

UNHCR. 2014. Children on the Run.

http://www.unhcrwashington.org/sites/default/files/1_UAC_Children\%20on \%20the\%20 Run_Full\%20Report.pdf (accessed 8 August 2014).

Waltz, Kenneth. 1959. Man, the State, and War. New York: Columbia University Press.

Williams, Robert E. 1986. "Christian Realism and 'the Bomb:' Reinhold Niebuhr and the Dilemmas of the Nuclear Age.” Journal of Church and State 28 (2): 289-304.

Yoder, John H. 1994. The Politics of Jesus. Grand Rapids: Eerdmans Press. 